\title{
A CASE OF MATERNITY TESTING: EXCLUSION BY POLYMORPHIC VNTR MARKERS OF DNA
}

\author{
Atsushi Akane, ${ }^{1}$ Hachiro Nakajima, ${ }^{2}$ Hiroshi Shiono, ${ }^{1}$ \\ Kazuo Matsubara, ${ }^{1}$ Masao Yamada, ${ }^{3}$ and Yasuo NaKagome ${ }^{3}$ \\ ${ }^{1}$ Department of Legal Medicine, Shimane Medical University, \\ Izumo 693, Japan \\ ${ }^{2}$ Department of Forensic Medicine, Tokyo Medical and Dental University, \\ Yushima, Bunkyo-ku, Tokyo 113, Japan \\ ${ }^{3}$ Department of Congenital Abnormalities Research, National Children's Medical \\ Research Center, Taishido, Setagaya-ku, Tokyo 154, Japan
}

\begin{abstract}
Summary The genetic markers of a Korean woman and her allegedly adopted child were compared to test her maternity. None of 21 conventional markers, including 8 red cell antigens, 6 red cell enzymes, and 7 serum proteins, excluded the maternity. These results indicate a maternal probability of 0.31 which was too low to conclude the true maternity. Human leukocyte antigen (HLA)-A, -B, -C and -DR haplotyping was also uninformative in this case. The maternity was consequently excluded by the observation of a difference in 2 of 5 variable number of tandem repeat (VNTR) markers.
\end{abstract}

Key Words maternity testing, DNA analysis, VNTR markers

\section{INTRODUCTION}

Parentage is usually determined using such conventional genetic markers as red blood cell antigens, red cell enzymes, serum proteins and human leukocyte antigens (HLA). In addition, the variations of DNA such as restriction fragment length polymorphisms (RFLPs) are analyzed for the purpose (Akane et al., 1990). Many RFLP markers have been found on various regions of every chromosome, and, among them, hypervariable RFLPs or variable number of tandem repeat

Received August 23, 1990; Accepted September 10, 1990.

Abbreviations: PGM1, phosphoglucomutase 1; ACP1, acid phosphatase 1; ESD, esterase D; GPT, soluble glutamic-pyruvate transaminase; PGD, phosphogluconate dehydrogenase; GLO1, glyoxalase 1; HP, haptoglobin; GC, group-specific component; TF, transferrin; PI, $a_{1}$-antitrypsin; AHSG, $a_{2} \mathrm{HS}$-glycoprotein; Gm, $\mathrm{H}$ chain of $\gamma$-globulin; $\mathrm{Km}, \mathrm{L}$ chain of $\gamma$-globulin. 
(VNTR) markers, which were developed by Nakamura et al. (1987a), have proved to be the most informative for this purpose (Akane et al., 1990; Yokoi et al., 1990).

Because the blood relationship between a mother and her child is usually obvious owing to the fact of delivery, it is uncommon to have to determine the maternity. Here is a peculiar case of maternity testing, in which only the VNTR markers were useful for the exclusion.

\section{CASE REPORTS}

A Korean woman claimed that a child legally registered as her progeny was not actually her child and that the child was the progeny of her husband and another woman. Her husband had deceased before the analysis was performed. The genetic markers of the child and the alleged mother were analyzed to test the maternity.

\section{ANALYSIS OF GENETIC MARKERS}

Conventional markers. Twenty-one conventional markers and HLA types were analyzed by antisera or by electrophoresis as described elsewhere (Akane et al., 1990).

RFLPs. All VNTR probes used (Nakamura et al., 1987a-1988b) were kindly supplied from the Japanese Cancer Research Resources Bank. DNA samples were extracted from peripheral blood leukocytes, and RFLPs were analyzed by Southern blotting method using ${ }^{32} \mathrm{P}$-labeled probes as reported before (Akane et al., 1990).

\section{RESULTS AND DISCUSSION}

Blood groups are used in elucidating problems of doubtful parentage because of their appearance in an individual in accordance with Mendelian laws of inheritance. Results in analyses of 21 conventional genetic markers and HLA types are shown in Table 1. The maternity of the alleged mother was excluded by none of these markers. The probability of maternity calculated from 21 markers based on allele frequencies in Korean population by the formula of Essen-Möller was 0.31, which was too low to affirm the maternity. Since frequencies of HLA haplotypes in Korean are unknown, the probability from HLA could not be obtained.

Then, 5 VNTR probes were additionally utilized for analyses of RFLPs as shown in Table 2. When pYNH24 or pEFD75.1 was used, each allele detected in the child's DNA was different from either of two alleles found in the alleged mother's genotype (Fig. 1): The maternity was excluded by 2 of 5 VNTR markers.

When hypervariable RFLPs are analyzed, the possibility of mutation event 
Table 1. Conventional geneticimarkers.

\begin{tabular}{|c|c|c|c|c|c|}
\hline $\begin{array}{l}\text { Marker } \\
\text { systems }\end{array}$ & $\begin{array}{l}\text { Alleged } \\
\text { mother }\end{array}$ & Child & $\begin{array}{l}\text { Marker } \\
\text { systems }\end{array}$ & $\begin{array}{l}\text { Alleged } \\
\text { mother }\end{array}$ & Child \\
\hline \multicolumn{3}{|c|}{ Red cell antigens } & \multicolumn{2}{|c|}{ Serum proteins } & \\
\hline $\mathrm{ABO}$ & B & B & HP & 2 & $2-1$ \\
\hline MNS & MNs & Ms & $\mathrm{GC}$ & $2-1 S$ & $2-1 F$ \\
\hline $\mathrm{Rh}$ & $\mathrm{CcDEe}$ & $\mathrm{CcDEe}$ & $\mathrm{TF}$ & $\mathrm{Cl}$ & $\mathrm{C} 1$ \\
\hline Duffy & $a+b-$ & $a+b+$ & PI & MI & MI \\
\hline Kidd & $a-b+$ & $a+b+$ & AHSG & $2-1$ & $2-1$ \\
\hline $\mathrm{P}$ & $\mathbf{P}_{1}$ & $\mathrm{P}_{2}$ & $\mathrm{Gm}$ & axg & axg \\
\hline Lewis & $a-b+$ & $a+b-$ & $\mathrm{Km}$ & $1-b+$ & $1+b+$ \\
\hline Diego & $a-b+$ & $a-b+$ & & & \\
\hline \multicolumn{3}{|c|}{ Red cell enzymes } & HLA & & \\
\hline PGM1 & $1 \mathrm{~A} 2 \mathrm{~B}$ & $1 \mathrm{~A}$ & A & A2,A11 & $\mathrm{A} 2, \mathrm{~A} 24$ \\
\hline $\mathrm{ACP} 1$ & B & $\mathrm{B}$ & B & B35,Bw62 & B35,B51 \\
\hline ESD & 1 & $2-1$ & $\mathrm{C}$ & $\mathrm{Cw} 3, \mathrm{Cw} 4$ & Cw4,- \\
\hline GPT & $2-1$ & $2-1$ & DR & DR4,DR9 & DR4,DR9 \\
\hline PGD & A & A & & & \\
\hline GLO1 & $2-1$ & 2 & & & \\
\hline
\end{tabular}

Table 2. VNTR markers.

\begin{tabular}{lllll}
\hline \multirow{2}{*}{ Probe } & Locus & Restriction & \multicolumn{2}{c}{ Genotypes a } \\
\cline { 5 - 6 } & & enzyme & Mother & Child \\
\hline pYNH24 ${ }^{\mathrm{b}}$ & D2S44 & MspI & $3.00,1.57$ & $2.40,1.70$ \\
pTHH59 & D17S4 & PvuII & $1.80,1.50$ & $1.78,1.50$ \\
pEFD75.1 & D10S25 & TaqI & $2.41,2.38$ & $2.17,2.17$ \\
pEFD126.3 & D9S7 & TaqI & $2.70,2.70$ & $2.80,2.70$ \\
pYNZ2 & D1S57 & RsaI & $2.70,1.60$ & $2.15,1.60$ \\
\hline
\end{tabular}

a Genotypes are represented by restriction fragment lengths $(\mathrm{kb})$ of alleles. $\mathrm{b}$ Maternity was excluded.

to generate a new length allele should always be taken into consideration (Akane et al., 1990). For example, the spontaneous mutation rate might be as high as $5 \%$ for the most unstable hypervariable minisatellite locus (Jeffreys et al., 1988). The mutation rate in each VNTR locus is thought to be very low: Only one case had been reported (Wolff et al., 1988). Nevertheless, parentage could not be excluded when only one VNTR marker shows mismatching between genotypes of the alleged parent and the child in question whereas other many markers do not. Since the probability 


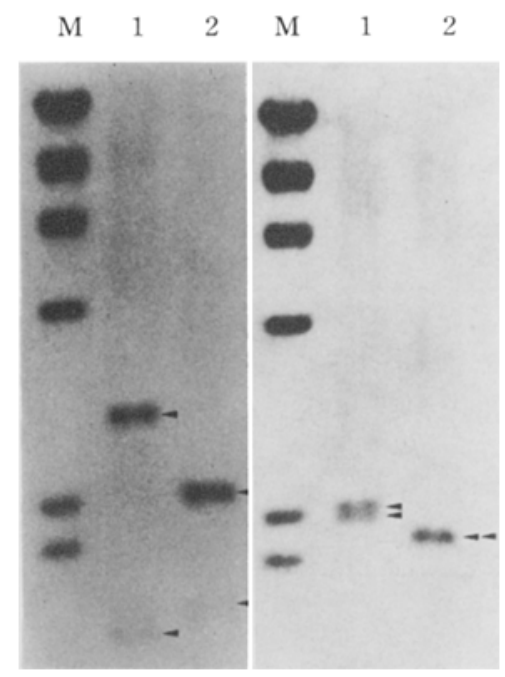

Fig. 1. The DNA alleles detected by pYNH24 (left) and pEFD75.1 (right) in the alleged mother (lane 1) and the child (lane 2). Lane $\mathbf{M}$ includes a molecular weight standard marker, $\lambda$-HindIII digest. Only by these probes could the maternity be excluded.

of mutations occurring on more than two VNTR loci at the same time is low (Wolff et al., 1988), mismatching in more than two VNTR markers should be required for the exclusion of parentage, as in this case.

Parentage is usually determined by conventional genetic markers such as red cell antigens, red cell enzymes, serum proteins and human leukocyte antigens. Human genomic DNA includes numerous variations and conventional markers are reffections of only a small fraction of them. By DNA technology, it has become possible to detect DNA variations in various regions of individual human chromosomes. When RFLPs are analyzed in addition to the conventional genetic markers in parentage testing, the blood relationship can be determined more minutely and exactly.

Acknowledgments Supported in part by grants from the Ministry of Education, Science and Culture and the Ministry of Health and Welfare of Japan.

All DNA probes were kindly supplied from the Japanese Cancer Research Resources Bank. The authors are indebted to Dr. S.B. England for proof reading the manuscript.

\section{REFERENCES}

Akane, A., Matsubara, K., Shiono, H., Yuasa, I., Yokota, S., Yamada, M. and Nakagome, Y. 1990. Paternity testing: blood group systems and DNA analysis by VNTR markers. $J$. Forensic: Sci. 35: 1217-1225.

Jeffreys, A.J., Royle, N.J., Wilson, V. and Wong, Z. 1988. Spontaneous mutation rates to new length alleles at tandem-repetitive hypervariable loci in human DNA. Nature 332: 278-281. 
Nakamura, Y., Leppert, M., O’Connell, P., Wolff, R., Holm, T., Culver, M., Martin, C., Fujimoto, E., Hoff, M., Kumkin, E. and White, R. 1987a. Variable number of tandem repeat (VNTR) markers for human gene mapping. Science 235: 1616-1622.

Nakamura, Y., Gillilan, S., O'Connel, P., Leppert, M., Lathrop, G.M., Lalouel, J.-M. and White, R. 1987b. Isolation and mapping of a polymorphic DNA sequence pYNH24 on chromosome 2 (D2S44). Nucleic Acids Res. 15: 10073.

Nakamura, Y., Fujimoto, E., O'Connel, P., Leppert, M., Lathrop, G.M., Lalouel, J.-M. and White, R. 1987c. Isolation and mapping of a polymorphic DNA sequence (pEFD126.3) on chromosome 9q (D9S7). Nucleic Acids Res. 15: 10607.

Nakamura, Y., Holm, T., Gillilan, S., Leppert, M., O'Connel, P., Lathrop, G.M., Lalouel, J.-M. and White, R. 1988a. Isolation and mapping of a polymorphic sequence (pTHH59) on chromosome 17q (D17S4). Nucleic Acids Res. 16: 3598.

Nakamura, Y., Culver, M., Sergeant, L., Leppert, M., O'Connel, P., Lathrop, G. M., Lalouel, J.-M. and White, R. 1988b. Isolation and mapping of a polymorphic DNA sequence (pYNZ2) on chromosome 1p (D1S57). Nucleic Acids Res. 16: 4747.

Wolff, R.K., Nakamura, Y. and White, R. 1988. Molecular characterization of a spontaneously generated new allele at a VNTR locus: No exchange of flanking DNA sequences. Genomics 3: 247-351.

Yokoi, T., Nata, M., Odaira, T. and Sagisaka, K. 1990. Hypervariable polymorphic VNTR loci for parentage testing and individual identification. Jpn. J. Human Genet. 35: 179-188. 